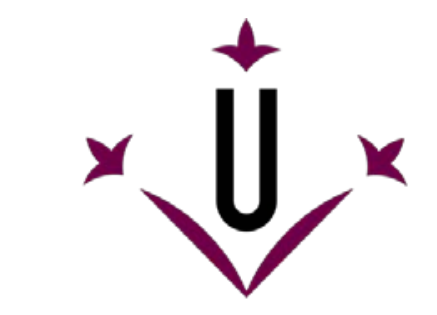

Universitat de Lleida

Document downloaded from:

http://hdl.handle.net/10459.1/59394

The final publication is available at:

https://doi.org/10.1177/1082013214541863

Copyright

(c) SAGE Publications, 2015 


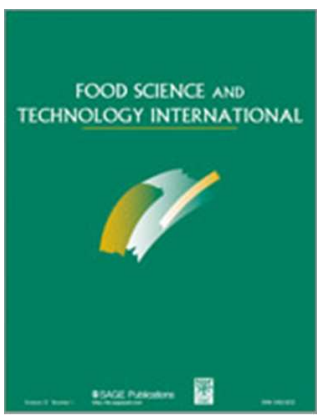

\section{Post-storage cell wall metabolism in two sweet cherry (Prunus avium L.) cultivars displaying different postharvest performance.}

\begin{tabular}{|c|c|}
\hline Journal: & Food Science and Technology International \\
\hline Manuscript ID: & FSTI-14-0139.R1 \\
\hline Manuscript Type: & Research Article \\
\hline Subject category: & Physical, Chemical and Sensory Properties \\
\hline Date Submitted by the Author: & $\mathrm{n} / \mathrm{a}$ \\
\hline Complete List of Authors: & $\begin{array}{l}\text { Belge, Burcu; University of Lleida, Chemistry } \\
\text { Comabella, Eva; University of Lleida, Chemistry } \\
\text { Graell, Jordi; University of Lleida, Food Technology } \\
\text { Lara, Isabel; University of Lleida, Chemistry }\end{array}$ \\
\hline Keywords: & $\begin{array}{l}\text { Cell wall polysaccharides, Cold storage, Enzymes, Fruit postharvest, Fruit } \\
\text { storage }\end{array}$ \\
\hline Abstract: & $\begin{array}{l}\text { The biochemical processes underlying firmness loss of sweet cherry } \\
\text { (Prunus avium L.) fruit are poorly understood. Studies on cell wall } \\
\text { metabolism of sweet cherry have been generally undertaken during on-tree } \\
\text { development or at harvest maturity, while published reports on } \\
\text { postharvest changes are scarce and fragmentary. In this work, cell wall } \\
\text { modifications after storage at } 0{ }^{\circ} \mathrm{C} \text { were studied in two cherry cultivars } \\
\text { ('Celeste' and 'Somerset') displaying different postharvest potential. } \\
\text { Firmness was largely determined by the yields of the Na2CO3- and } \mathrm{KOH}- \\
\text { soluble fractions, enriched in covalently-bound pectins and in matrix } \\
\text { glycans, respectively, and correlated well with ascorbic acid contents. The } \\
\text { yields of these two cell wall fractions were correlated inversely with PME } \\
\text { and EGase activities, indicating a relevant role of these two enzymes in } \\
\text { postharvest firmness changes in sweet cherry. The amount of solubilised } \\
\text { cell wall materials was closely associated to the contents of } \\
\text { dehydroascorbic acid, suggesting a possible role for oxidative mechanisms } \\
\text { in cell wall disassembly. These data may help understanding the evolution } \\
\text { of fruit quality during the marketing period, and give hints for the design of } \\
\text { suitable management strategies to preserve key attributes. }\end{array}$ \\
\hline
\end{tabular}




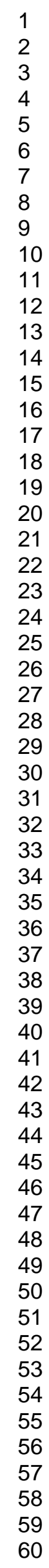

SCHOLARONE ${ }^{\text {'m }}$

Manuscripts

7

10

11

12

13

16

17

18

19

20

22

24

26

27

29

30

33

34

35

36

39

40

41

43

44

45

46

47

48

50

51

52

55

56

57

58

60

http://mc.manuscriptcentral.com/fsti 


\section{POST-STORAGE CELL WALL METABOLISM IN TWO SWEET}

2 CHERRY (Prunus avium L.) CULTIVARS DISPLAYING DIFFERENT

3 POSTHARVEST PERFORMANCE

4

5 Burcu Belge ${ }^{1,3}$, Eva Comabella ${ }^{1,3}$, Jordi Graell ${ }^{2,3}$, Isabel Lara ${ }^{1,3}$ *

6 Universitat de Lleida, Rovira Roure 191, 25198 Lleida, Spain

$7 \quad{ }^{1}$ Departament de Química

$8 \quad 2$ Departament de Tecnologia d'Aliments

$9 \quad{ }^{3}$ Unitat de Postcollita-XaRTA

10

11

12

$13 *$ Corresponding author: Isabel Lara

14

e-mail: lara@quimica.udl.cat, Tel: +34 973702526

15 
16 Post-storage cell wall metabolism in two sweet cherry (Prunus avium 1.)

17 cultivars displaying different postharvest performance

18

19

20

21

22

23

24

25

26

27

28

29

30

31

32

33

34

35

36

37

38

\section{Abstract}

The biochemical processes underlying firmness loss of sweet cherry (Prunus avium L.) fruit are poorly understood. Studies on cell wall metabolism of sweet cherry have been generally undertaken during on-tree development or at harvest maturity, while published reports on postharvest changes are scarce and fragmentary. In this work, cell wall modifications after storage at $0^{\circ} \mathrm{C}$ were studied in two cherry cultivars ('Celeste' and 'Somerset') displaying different postharvest potential. Firmness was largely determined by the yields of the $\mathrm{Na}_{2} \mathrm{CO}_{3}$ - and $\mathrm{KOH}$-soluble fractions, enriched in covalently-bound pectins and in matrix glycans, respectively, and correlated well with ascorbic acid contents. The yields of these two cell wall fractions were correlated inversely with PME and EGase activities, indicating a relevant role of these two enzymes in postharvest firmness changes in sweet cherry. The amount of solubilised cell wall materials was closely associated to the contents of dehydroascorbic acid, suggesting a possible role for oxidative mechanisms in cell wall disassembly. These data may help understanding the evolution of fruit quality during the marketing period, and give hints for the design of suitable management strategies to preserve key attributes.

Keywords:

Ascorbate; cell wall; cold storage; enzymes; Prunus avium L.; postharvest 


\section{INTRODUCTION}

Keeping and handling potential of sweet cherry (Prunus avium L.) fruit is limited, owing to rapid postharvest deterioration and to high susceptibility to infections and mechanical injuries.

These fruit must be harvested fully ripe in order to achieve good eating quality, surface colour and soluble solids content (SSC) being the main criteria commonly used to define harvest maturity (Romano et al., 2006). While the eating quality of sweet cherries is dependent upon SSC, titratable acidity (TA), SSC/TA ratio, aroma and flavour, handling options are determined largely by firmness, and indeed rapid softening rates of these fruit are closely related to their high perishability. These characteristics restrict drastically their storage potential and marketing possibilities after harvest.

Ripening-related firmness loss is commonly attributed to modifications in cell wall composition and structure, driven by the cooperative, tightly-regulated action of numerous related proteins. Profound differences exist reportedly in the extent and enzyme regulation of ripening-related modifications of cell wall polysaccharides among fruit species or even cultivars (Goulao and Oliveira, 2008). For sweet cherry, the biochemical processes underlying postharvest firmness loss are poorly understood. Size exclusion chromatography studies revealed negligible pectin depolymerisation during ripening of cherry fruit, suggesting that fruit softening does not depend on this event (Batisse et al., 1994). Moreover, texture differences between firm and soft cherry fruit were also not related to depolymerisation of the pectin backbone, but rather to differences in the structure and size of the pectin side-chains (Batisse et al., 1996; Salato et al., 2013). A survey of six cherry genotypes with differing firmness levels indicated that cell walls of firmer cultivars contained higher amounts of alcohol-insoluble residues, of tightly-bound pectins and, although not consistently for all genotypes examined, of xyloglucans (Choi et al., 2002a). 
64

65

66

67

68

69

70

71

72

73

74

75

76

77

A few studies have also addressed the changes in some cell wall-modifying enzyme activities in relation to a putative role in firmness loss of cherry fruit. Polygalacturonase (PG) activity increases reportedly late during sweet cherry development, suggesting that early fruit softening taking place at the onset of fruit ripening is unrelated to PG-mediated pectin disassembly, while carboxymethyl (Cx)-cellulase (currently termed endo- $\beta$-1,4-glucanase), $\beta$ galactosidase and $\beta$-glucosidase activities might be involved in the initiation of the softening process (Choi et al., 2002b). Deposition of active $\beta$-glucosidase in the cell wall has been demonstrated during ripening of cherry fruit, and the enzyme characterised to possess hydrolytic activity against complex glycans (Gerardi et al., 2001). The highest $\beta$-galactosidase activity during on-tree development of 'Bing' fruit was observed approximately two weeks prior to fruit maturity, and suggested to contribute to cell wall hydrolysis during sweet cherry fruit softening (Andrews and $\mathrm{Li}, 1994$ ). Functional characterisation of the enzyme demonstrated high specificity for $p$-nithophenyl- $\beta$-D-galactopyranoside, together with increased activity during ripening (Gerardi et al., 2012).

Studies on cell wall metabolism of sweet cherry have been undertaken during on-tree development or at harvest maturity, while we are not aware of any published reports on postharvest changes in cell walls of these fruit. Additionally, there is experimental evidence that non-enzymatic mechanisms may be involved in the oxidative scission of cell wall polysaccharides in other fruit species such as tomato, strawberry, banana or longan, and particular attention has been focused on the possible role of ascorbic acid and its oxidation derivatives (Fry, 1998; Agius et al., 2003; Cheng et al., 2008; Duan et al., 2011). For these reasons, we undertook this study on cell wall modifications during cold storage of 'Celeste' and 'Somerset' sweet cherry fruit, with special emphasis on the possible role of enzymatic and non-enzymatic factors on postharvest cell wall disassembly. 
MATERIALS AND METHODS

91

\section{Plant material and postharvest handling}

Cherry fruit (Prunus avium L. 'Celeste' and 'Somerset') were hand-collected in 2011 (May $23^{\text {rd }}$ and June $7^{\text {th }}$, respectively) from a family-led orchard located in Corbins, in the area of Lleida (NE Spain), at commercial maturity on the basis of size and colour according to the usual practices in the producing area. Samples were selected for uniformity and absence of visible defects and damages, transported directly to the laboratory, and stored at $0{ }^{\circ} \mathrm{C}$ and $92 \%$ relative humidity under regular air for up to 14 ('Celeste') or 28 ('Somerset') days. Fruit were analysed immediately after harvest and upon removal from storage, with or without 3 additional days at $20{ }^{\circ} \mathrm{C}$ to simulate commercial shelf life. Tissue samples from the pericarp of 30 fruit (three replicate samples $\times 10$ fruit per sample) were taken at each sampling date,

102 frozen in liquid nitrogen, freeze-dried, powdered, and kept at $-80{ }^{\circ} \mathrm{C}$ for subsequent 103 biochemical analyses.

104 determine weight loss (\%) regarding harvest date. Fungal decay was expressed as a

111 percentage of fruit affected. For the assessment of juiciness, three replicate samples (10 fruit 112 each) were stoned and squeezed until no more juice was released. After filtration, the volume 113 of juice recovered was measured, and expressed as $\mathrm{mL} 100 \mathrm{~g}^{-1}$ fresh weight. Soluble solids 
114 content (SSC) and titratable acidity (TA) were assessed in juice obtained as described above.

115 SSC was determined with a hand-held refractometer (Atago, Tokyo, Japan), and results 116 expressed as ${ }^{\circ}$ Brix. For TA determination, $10 \mathrm{~mL}$ of juice were diluted in $10 \mathrm{~mL}$ distilled 117 water, and titrated with $0.1 \mathrm{M} \mathrm{NaOH}$ to $\mathrm{pH}$ 8.1; results were given as g malic acid $\mathrm{L}^{-1}$. Skin 118 colour was determined at two opposite equatorial points of 30 fruit using a portable 119 tristimulus colorimeter (Chroma Meter CR-200, Minolta Corp., Osaka, Japan), with CIE $\mathrm{D}_{65}$ 120 illuminant and $8 \mathrm{~mm}$ aperture diameter. Lightness $\left(\mathrm{L}^{*}\right)$ values were recorded, and hue angle 121 was calculated from $\mathrm{a}^{*}$ and $\mathrm{b}^{*}$ parameters as $\operatorname{arctg} \mathrm{b}^{*} / \mathrm{a}^{*}$.

122

\section{Extraction, fractionation and analysis of cell wall materials}

124

125

The phenol:acetic acid:water $(2: 1: 1, \mathrm{w} / \mathrm{v} / \mathrm{v})(\mathrm{PAW})$ method was used for the extraction of cell wall materials (CWM) from lyophilised tissue (3 g) according to Redgwell et al. (1992). The pellet obtained after PAW extraction was resuspended in water and centrifuged again. The PAW and water wash supernatants were combined, dialysed (mol. wt. cut-off 7000) for two days against Milli-Q water at $4{ }^{\circ} \mathrm{C}$, and centrifuged again to sediment out the precipitate formed during the dialysis. The combined supernatant (henceforth, PAW-soluble fraction; $\mathrm{PAW}_{\text {sf }}$ ) was recovered, lyophilised and weighed. The PAW-insoluble pellet was washed twice in acetone, recovered by vacuum filtration, lyophilised and weighed to determine yield of CWM, expressed as \% (w/w) FW. For further fractionation, CWM (100 mg) from each replicate were extracted sequentially with water, $0.05 \mathrm{M}$ cyclohexane-trans-1,2-diamine tetraacetate (CDTA), $0.05 \mathrm{M} \mathrm{Na}_{2} \mathrm{CO}_{3}$, and $4 \mathrm{M} \mathrm{KOH}$ as described previously (Selvendran and O’Neill, 1987), in order to fractionate water-soluble pectin, non-covalently-bound pectin, covalently-bound pectin and matrix glycans (hemicelluloses), respectively. Each fraction was filtered through Miracloth, extensively dialysed (mol. wt. cut-off 7000) against Milli-Q water

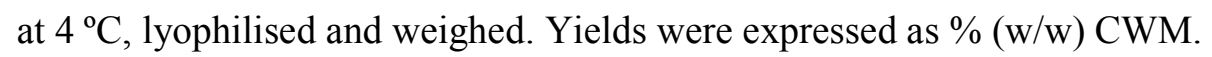


Samples of total CWM, CDTA- and $\mathrm{Na}_{2} \mathrm{CO}_{3}$-soluble fractions (30-35 $\mathrm{mg}$ each) were hydrolysed with $12 \mathrm{M}$ sulphuric acid for further analysis as described previously (Ortiz et al., 2011a). Uronic acid content in the hydrolysate was measured by the $m$-hydroxydiphenyl method (Blumenkrantz and Asboe-Hansen, 1973) using galacturonic acid as a standard. Total neutral sugars were estimated at $490 \mathrm{~nm}$ by the phenol-sulphuric acid assay (Dubois et al., 1956), with galactose as the standard.

The colorimetric ascorbate assay (Gillespie and Ainsworth, 2007) was used to analyse the contents of ascorbic (AA) and dehydroascorbic (DHA) acid in samples (40 mg) of lyophilised tissue. Determinations were done in triplicate, and data given as $\mu \mathrm{mol} \mathrm{gDW}^{-1}$.

\section{Extraction and assay of cell wall-modifying enzyme activities}

For the extraction of polygalacturonase (exo-PG; EC 3.2.1.67 and endo-PG; EC 3.2.1.15), pectinmethylesterase (PME; EC 3.1.1.11), pectate lyase (PL; EC 4.2.2.2) and endo-1,4- $\beta$-Dglucanase (EGase; EC 3.2.1.4) activities, a 10\% (w/v) pulp homogenate was prepared by homogenising $100 \mathrm{mg}$ of freeze-dried pulp tissue in an extraction buffer prepared according to Lohani et al. (2004). PG activity was determined on apple pectin (d.e. $70-75 \%$ ) as described previously (Pathak and Sanwall, 1998), with galacturonic acid (GalUA) as a standard. One unit (U) of PG activity was defined as the liberation of $1 \mu \mathrm{mol}$ of GalUA $\mathrm{min}^{-1}$. PME activity was measured according to Hagerman and Austin (1986). For the assay, the reaction mixture contained enzyme extract, apple pectin and bromothymol blue prepared as described previously (Alonso et al., 1997). One unit (U) of PME activity was defined as the decrease of one unit of $\mathrm{A}_{620} \mathrm{~min}^{-1}$. PL activity was assayed with apple pectin as the substrate according to Moran et al. (1968) as modified by Lohani et al. (2004). One unit (U) of PL activity was defined as the increase of one unit of $\mathrm{A}_{235} \mathrm{~min}^{-1}$. For the assessment of EGase activity, the DNS method (Miller, 1959), with carboxymethylcellulose as the assay substrate, 
was used to determine the amount of reducing sugars released, with glucose as a standard.

One unit $(\mathrm{U})$ of EGase activity was defined as the release of $1 \mu \mathrm{mol}$ of glucose $\mathrm{min}^{-1}$.

For the extraction of $\beta$-galactosidase ( $\beta$-Gal; EC 3.2.1.23), $\beta$-xylosidase ( $\beta$-Xyl; EC 3.2.1.37) and $\alpha$-L-arabinofuranosidase (AFase; EC 3.2.1.55) activities, a 10\% (w/v) pulp homogenate was prepared by homogenising $100 \mathrm{mg}$ of freeze-dried pulp tissue in extraction buffer prepared according to previous work (Vicente et al., 2005). $\beta$-Gal, $\beta$-Xyl and AFase activity assays were undertaken in the crude extract as described in Vicente et al. (2005) and

Wei et al. (2010), respectively. One unit (U) of $\beta$-Gal was defined as the liberation of $1 \mu \mathrm{mol}$

172 of $p$-nitrophenol $\min ^{-1}$ from $p$-nitrophenyl- $\beta$-D-galactopyranoside. One unit (U) of AFase or $173 \beta$-Xyl activity was defined as the liberation of 1 nmol of $\mathrm{p}$-nitrophenol $\mathrm{min}^{-1}$ from $p$ 174 nitrophenyl- $\alpha$-L-arabinofuranoside or $p$-nitrophenyl- $\beta$-D-xylopyranoside, respectively.

Total protein content in the crude extracts was determined with the Bradford (1976) method, using BSA as a standard. All analyses were done in triplicate, and results were expressed as specific activity $\left(\mathrm{U} \mathrm{mg}^{-1}\right.$ protein). (CAMO ASA, 2004).

\section{Statistical and multivariate analysis}

Results were treated for multiple comparisons by analysis of variance (ANOVA), followed by the least significant difference (LSD) Fisher's test at $P \leq 0.05$ with the Minitab 16 software package (Minitab Inc., UK). Partial least square regression (PLSR) was also used as a predictive method to relate a matrix of dependent variables $(Y)$ to a set of explanatory variables $(X)$ in a single estimation procedure, using the Unscrambler version 9.1.2 software 
189

190

191

192

193

194

195

196

197

198

199

200

201

202

203

204

205

206

207

208

209

210

211

212

213

\section{RESULTS AND DISCUSSION}

The usual standard indicators used to evaluate commercial quality of fruit indicated that samples were picked at a suitable maturity stage according to the standards in the producing area (Table 1). 'Somerset' fruit were in average larger and heavier than 'Celeste' cherries, and also displayed higher firmness, juiciness, SSC and TA values, besides being darker and redder. 'Celeste' cherries were analysed after 0,7 and 14 days of cold storage. Because 'Somerset' fruit display better keeping potential, the analyses on this cultivar were undertaken after storing the samples at $0{ }^{\circ} \mathrm{C}$ during 0,14 and 28 days. For clarity, Tables and Figures show results corresponding to 0 and 14 days of storage uniquely. However, all samples (2 cultivars $\times 3$ storage periods $\times 2$ shelf life periods) were used for the development of the regression models.

\section{Fruit quality and cell wall materials after cold storage}

Firmness of 'Celeste' fruit declined significantly after 14 days at $0{ }^{\circ} \mathrm{C}$, whereas that of 'Somerset' cherries increased (Table 2), indicating a tightening effect of cold temperature on fruit tissues as observed elsewhere for 'Pájaro' strawberries (Lara et al., 2004). 'Somerset' samples actually retained high levels of this attribute ( $>80$ Durofel units) throughout the whole experimental period of 28 days (not shown). In addition, weight loss rates were lower in 'Somerset' than in 'Celeste' fruit, but in contrast 'Somerset' cherries suffered from higher incidence of fungal infections (Table 2).

Insoluble and PAW-soluble cell wall materials were extracted from fruit samples in order to assess possible relationships to some shelf life potential-related attributes. Different trends were observed for each cultivar considered. For 'Celeste', increased yields of insoluble cell wall materials $(\mathrm{CWM})$ and decreased amounts of PAW-soluble materials $\left(\mathrm{PAW}_{\mathrm{sf}}\right)$, indicative 
214 of the degree of in vivo solubilisation of cell wall polysaccharides, were observed in fruit after

215 a two-week cold storage period (Table 3). These changes resulted in remarkably augmented

216 CWM:PAW sf ratios as compared with values at harvest (120.8 vs. 22.2) in spite of decreased

217 fruit firmness. For 'Somerset', the increase in firmness after cold storage of fruit was

218 accompanied by a two-fold increment in CWM yields recovered from fruit pericarp.

219 However, firmness remained at similar levels after fruit was kept 3 days at $20^{\circ} \mathrm{C}$ thereafter,

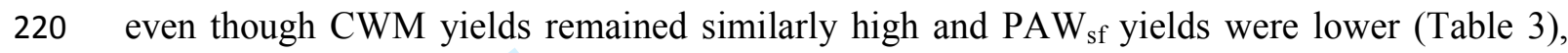

221 leading likewise to increased CWM:PAW sf ratios (132.3 vs. 76.1). This disagrees with

222 previous observations on fruit displaying non-melting as well as melting softening patterns,

223 such as apple (Ortiz et al., 2011a) and nectarine (Ortiz et al., 2010), for which we found

224 declining CWM:PAW sf ratios with concomitant firmness loss during on-tree ripening,

225 reflecting progressive solubilisation of cell wall polymers during the process. However, the

226 biochemical mechanisms underlying firmness changes may be different during ripening and

227 during the postharvest period of fully ripe fruit. These discrepancies may also be placed in

228 connection with the view that noticeable differences exist among fruit species in the

229 mechanisms involved in ripening-related firmness loss (Goulao and Oliveira, 2008), and

230 suggest that additional processes besides cell wall modifications may play a role in sweet

231 cherry fruit softening. One of such mechanisms may be related to water loss rates, which in

232 turn are dependent upon the properties of the fruit cuticle. Indeed, there is experimental

233 evidence for some fruit species that firmness loss shows good correspondence to the

234 alterations in cell turgor taking place during ripening (Lara et al., 2014). The water-proofing

235 properties of the cuticle depend to a large extent on the composition of cuticular waxes. For

236 fruit species within the Solanaceae family, such as tomato or pepper, it has been reported that

237 the ratio of alkanes to triterpenoids (Vogg et al., 2004) or to triterpenoids plus sterols (Parsons

238 et al., 2012) correlated inversely to dehydration rates. Our own results (unpublished data) 
239 indicated ratios of 0.18 and 0.33 for 'Celeste' and 'Somerset' at harvest, respectively, which

240 would be consistent with higher firmness and lower water loss rates in the latter (Table 2).

241 Cell wall status may be more properly described by the specific composition and 242 structure of the cell wall polymers, rather than by CWM:PAW sf ratios. When the insoluble 243 cell wall materials obtained from the samples were fractionated and analysed, cultivar-related 244 differences were found, which might be related to the different keeping potential in each case. 245 For both cultivars, yields of the chelator-soluble fraction $\left(\mathrm{CDTA}_{\mathrm{sf}}\right)$, enriched in pectins bound 246 non-covalently to the cell wall, did not change after keeping the samples at $0{ }^{\circ} \mathrm{C}$ during 14 247 days. However, different responses were observed for each cultivar considered after the 248 simulated commercialisation period at $20^{\circ} \mathrm{C}$ subsequent to cold storage. While for 'Celeste' 249 fruit lower CDTA $_{\text {sf }}$ yields were found as compared with non-refrigerated samples kept 3 days 250 at $20^{\circ} \mathrm{C}$ immediately after harvest, the opposite was found for 'Somerset samples (Table 3).

251 Differences were observed as well in the evolution of yields of the carbonate-soluble fraction $252\left(\mathrm{Na}_{2} \mathrm{CO}_{3 \mathrm{sf}}\right)$, representative of covalently-linked pectins, which decreased after cold storage of 253 'Somerset fruit while remaining at similar levels in 'Celeste' samples (Table 3). Moreover, 254 the percentages of both pectin-containing fractions over total insoluble materials were 255 generally higher in 'Somerset' than in 'Celeste' samples, which had considerably lower 256 firmness and more intense weight loss (Table 2). When the content of uronic acids was 257 analysed in total insoluble materials as well as in pectin-containing fractions, it was found that 258 uronic acid content in the $\mathrm{Na}_{2} \mathrm{CO}_{3}$-soluble fraction increased in both cultivars after storing the 259 fruit at $0{ }^{\circ} \mathrm{C}$ during 14 days. In contrast, uronic acids in the chelator-soluble fraction decreased 260 after cold storage in comparison with levels at harvest, although 'Somerset' cherries were 261 found to display higher contents than 'Celeste' fruit in all the sampling dates considered (Fig. 262 1). Differences were also observed in the dynamics of the potassium hydroxide-soluble 263 fraction $\left(\mathrm{KOH}_{\mathrm{sf}}\right)$, which contains mainly cell wall xyloglucans, 'Somerset' samples generally 
displaying also higher contents of this cell wall fraction (Table 3). Although levels of ascorbic acid, both reduced (AA) and oxidised (DHA), showed similar dynamics in both cultivars in response to storage conditions, very different contents were observed in each case, 'Somerset' samples displaying higher AA and lower DHA contents in comparison with 'Celeste' fruit (Table 4).

In order to assess possible relationships to firmness and other quality attributes, cell wall composition data, together with AA and DHA contents, were used as the potentially explanatory variables ( $X$-matrix) to develop a regression model. The corresponding correlations loadings plot (Fig. 2) shows that firmness was associated closely to yields of the $\mathrm{Na}_{2} \mathrm{CO}_{3}$-soluble fraction, enriched in covalently-linked pectins, to the levels of uronic acids in et al., 2005). with a previous report on six sweet cherry cultivars differing in firmness, which demonstrated that softer fruit had lower levels of these two fractions (Choi et al., 2002a). Interestingly, firmness was also related to AA contents, while more intense cell wall solubilisation, as indicated by higher yields of PAW- and water-soluble materials, was associated to dehydroascorbate (DHA) contents. Since AA and DHA contents were assessed in lyophilised pericarp tissue rather than in isolated cell wall fractions, these data should be considered with caution. However, they are consistent with previous reports that ascorbate-induced hydroxyl radicals can cause non-enzymatic, oxidative scission of cell wall polysaccharides and thus contribute to fruit softening (Fry, 1998; Cheng et al., 2008; Duan et al., 2011), and suggests a role for ascorbate in softening of cherry fruit. Actually, a highly positive correlation between total antioxidant activity and ascorbic acid content has been reported for cherry fruit (Serrano 


\section{Cell wall-modifying enzyme activities after cold storage}

290 Ripening-related modifications in cell wall composition and structure are commonly

291 attributed to the finely-tuned, coordinated action of a number of specific enzymatic and non292 enzymatic proteins on different cell wall polysaccharides, which eventually lead to cell wall 293 disassembly. The controlling mechanisms involved in this event, though, appear to vary 294 widely among species (Goulao and Oliveira, 2008). Historically, depolymerizing enzymes 295 acting on the pectin backbone, such as PG and PME, have been considered to play a central 296 role in fruit softening. More recently, pectate lyase (PL), a lyase which removes demethylated 297 uronic acid residues from the pectin backbone through a $\beta$-elimination mechanism, has 298 received increasing attention, and has been shown to contribute to firmness loss in some fruit 299 species, including banana (Domínguez-Puigjaner et al., 1997), strawberry (Jiménez-Bermúdez 300 et al., 2002), nectarine (Ortiz et al., 2010), peach (Ortiz et al., 2011b) and apple (Ortiz et al., 301 2011a, 2011c). Because PME catalyses the demethylation of galacturonosyl residues, which is 302 required for subsequent PG and PL depolymerising action (Bennett and Labavitch, 2008), this 303 enzyme activity is believed to be essential for ripening-related firmness loss. When these 304 activities were analysed, cultivar-specific differences were observed in their evolution after 305 harvest.

306 Cold storage did not cause significant changes in PME activity in 'Celeste' fruit, but 307 levels increased during the subsequent simulated shelf life period at $20{ }^{\circ} \mathrm{C}$ (Fig. $3 \mathrm{~A}$ ), while in 308 'Somerset' samples similar PME activity levels were observed both at harvest and in cold309 stored fruit (Fig. 3B). PG activity increased in 'Celeste' cherries after cold storage (Fig. 3A), 310 whereas similar levels as compared with those at harvest were observed in 'Somerset' fruit 311 (Fig. 3B), maybe in relation to the retention of higher firmness in these fruit (Table 2). For 312 both cultivars, PL activity levels did not show significant differences after cold storage, but an 313 increase was found when fruit were kept at $20^{\circ} \mathrm{C}$ thereafter for 3 days (Table 5). 
Current experimental evidence shows that cell wall disassembly is far more complex than

initially thought, and that other cell wall proteins may contribute significantly and decisively to this event. Actually, textural differences between crisp and soft cherry fruit are apparently related to structure and composition of pectin side-chains rather than to depolymerisation of the pectin backbone, which has been reported to be very limited (Batisse et al., 1996). Indeed, the highly branched structure of pectins is believed to control pore size in the cell wall, thus restricting the access of pectin backbone-acting enzymes to their substrates, and protecting cell wall polysaccharides from extensive depolymerisation by pectolytic enzymes (Goulao and Oliveira, 2008), even though high levels of pectolytic activity may be present. Removal of these galactosyl- and arabinosyl-containing pectin side-chains thus increases cell wall permeability and favours the access of PG, PL and PME to their backbone substrates. For cherry fruit, it has been reported that higher firmness was associated with higher degree of pectin branching (Batisse et al., 1996), although a recent study in which the degree of pectin branching in fruit of a soft ('Newstar') and a firm ('Sweetheart') cultivar was compared found the opposite (Salato et al., 2013). $\beta$-Gal and AFase act on these neutral sugar-rich pectin sidechains, and may therefore have a major role in pectin solubilisation.

A cell wall-associated sweet cherry $\beta$-galactosidase ( $\beta$-Gal) has been characterised to be active against complex glycans (Gerardi et al., 2012). Because the enzyme was the main glycosidase activity detected in sweet cherry extracts at different ripening stages, and increased notably during ripening, it was suggested to play a significant role in fruit softening. In this work, $\beta$-Gal activity levels rose in 'Celeste' samples both after cold storage and after 3 days of simulated commercial life at $20^{\circ} \mathrm{C}$ (Fig. 3A), whereas cold storage induced a sharp increase in activity levels of 'Somerset' fruit (Fig. 3B). AFase activity, which cleaves arabinosyl residues from pectin side-chains, was also assessed, and found to follow dissimilar trends in both cultivars, with significantly increased levels being found in 'Celeste' fruit after 
339 harvest regardless of temperature, whereas in 'Somerset' samples cold storage did not cause

340 significant differences in AFase activity (Table 5).

341 Since data indicated that firmness was associated to the yield of specific cell wall

342 fractions and to ascorbate content (Fig. 2), an additional regression model was developed in

343 order to aid the visualisation of relationships among the variables assessed. Yield and

344 composition of cell wall materials isolated from fruit were taken as the $\mathrm{Y}$ variables, with the

345 assessed pectolytic and non-pectolytic enzyme activities, together with AA and DHA

346 contents, as the potentially explanatory ( $X$ matrix) variables. The correlations loading plot for

347 this model (Fig. 4) shows that the yields of the $\mathrm{Na}_{2} \mathrm{CO}_{3}$-soluble fraction, found to relate

348 closely to fruit firmness (Fig. 2), were correlated inversely to PME activity levels, suggesting

349 a role in firmness loss. Actually, PME activity was also well correlated to $\mathrm{PAW}_{\text {sf }}$ and $\mathrm{W}_{\text {sf }}$

350 yields, indicative of the degree of solubilisation of cell wall materials, and associated to

351 higher DHA contents. This is interesting in regard of previous evidence that de-esterified

352 pectin is more susceptible to ascorbate-induced scission in vitro than methylesterified pectin,

353 and that the ability to release ascorbate into the apoplast increases during ripening of tomato

354 fruit (Dumville and Fry, 2003).

355 PG activity was apparently unrelated to firmness loss (Fig. 4), and PL activity levels were

356 moreover generally higher in firmer fruit (Tables 2 and 5), which de-emphasises the role of

357 these enzymes in postharvest firmness changes of cherry fruit. High levels of PG and PL

358 activity might be not really of consequence for extensive changes in cell wall polysaccharides,

359 as their action is dependent upon the availability and accessibility to their demethylated

360 backbone substrate.

361 Removal of methyl moieties by PME also confers an anionic charge to polyuronides, and

362 contributes to changes in the electric charge and to the acidification of the apoplast, thus

363 modifying the activity and mobility of other cell wall proteins. Indeed, the pH optimum of 4.0 
reported for sweet cherry $\beta$-Gal (Gerardi et al., 2012) is consistent with the idea of increased activity upon ripening-associated decrease of apoplastic pH (Almeida and Huber, 1999). Yet results do not support a key role for $\beta$-Gal in postharvest deterioration of 'Celeste' and 'Somerset' cherries, firmer fruit actually displaying higher activity levels (Fig. 4). This result is not in accordance with the proposed role on sweet cherry softening (Gerardi et al., 2012), and it also disagrees with previous results on other fruit species (Ortiz et al., 2011a, 2011b). However, Gerardi et al. (2012) reported that $\beta$-Gal activity increased at early stages of sweet cherry ripening but decreased in over-ripe fruit. Similar results were obtained for nectarine (Ortiz et al., 2010), where $\beta$-Gal levels increased at the initial phase of softening, prior to the onset of the melting-like drop in firmness, to remain steady thereafter. Thus, the association events. No apparent association to firmness changes was found either for AFase activity, which is also considered to contribute to these controlling mechanisms of cell wall porosity. However, it was found to relate closely to the yields and to total neutral sugar contents in the $\mathrm{CDTA}_{\mathrm{sf}}$, which is consistent with previous observations that a part of insoluble cell wall materials are reallocated transiently from the carbonate- to the chelator-soluble fraction of pectins during softening of some fruits (reviewed in Goulao and Oliveira, 2008; Duan at el., 2011).

Similarly to the observations for PME, the matrix glycan-degrading EGase activity was inversely correlated to firmness levels and to the contents of ascorbic acid, again suggesting that antioxidant activity may have a role in preventing extensive cell wall disassembly. This is also consistent with the finding that higher yields of the $\mathrm{KOH}$-soluble fraction of insoluble cell wall materials, which is enriched in hemicellulosic polymers, were associated to higher firmness values (Fig. 2). Contradictory reports on the relevance of this non-pectolytic activity for fruit softening have been published (Goulao and Oliveira, 2008), and it has been suggested 
389 that it might be related rather to cell wall extensibility at early stages of fruit development.

390 Activity levels decreased progressively during fruit development of 'Mondial Gala' apples

391 (Goulao et al., 2007) and 'Snow Queen' nectarines (Ortiz et al., 2010), and were reportedly

392 higher in firmer 'Golden Reinders' apples (Ortiz et al., 2011c). However, results of the 393 present study suggest that EGase activity may have a relevant role in postharvest firmness 394 loss of sweet cherry fruit, in agreement with observations during fruit development (Choi et 395 al., 2002b).

As the concluding remarks, total amount of insoluble cell wall materials was not a good predictor of firmness in 'Celeste' and 'Somerset' cherries. Further fractionation of these materials revealed that firmness was largely determined by $\mathrm{Na}_{2} \mathrm{CO}_{3 \mathrm{sf}}$ yields, representative of the amount of covalently-bound pectins, and to a lesser extent by $\mathrm{KOH}_{\text {sf }}$ yields, which contain 401 mainly the matrix glycans. Firmness was also associated to higher levels of ascorbic acid, 402 whereas the degree of solubilisation of cell wall materials was closely related to the contents 403 of dehydroascorbic acid, which suggest a possible role of oxidative mechanisms in cell wall 404 disassembly. PME and EGase activities, respectively a pectin- and a hemicellulose-degrading 405 enzyme, were inversely correlated with the yields of the firmness-determining $\mathrm{Na}_{2} \mathrm{CO}_{3}$ - and $406 \mathrm{KOH}$-soluble fractions, as well as with ascorbic acid contents. These data may help 407 understanding the evolution of fruit quality during the marketing period, and thus identifying 408 key involved factors which may give hints for the design of suitable management strategies to 409 preserve key attributes. 


\section{REFERENCES}

414

415

416

417

418

419

420

421

422

423

424

425

426

427

428

429

430

431

432

Agius F, González-Lamothe R, Caballero JL, Muñoz-Blanco J, Botella MA and Valpuesta V. (2003). Engineering increased vitamic C levels in plants by overexpressing of a Dgalacturonic acid reductase. Nature Biotechnology 21: 177-181.

Almeida DPF and Huber DJ. (1999). Apoplastic pH and inorganic ion levels in tomato fruit: a potential means for regulation of cell wall metabolism during ripening. Physiologia Plantarum 105: 506-512.

Alonso J, Howell N and Canet W. (1997). Purification and characterisation of two pectinmethylesterases from persimmon (Diospyros kaki). Journal of the Science of Food and Agriculture 75: 352-358.

Andrews PK and Li S. (1994). Partial purification and characterization of $\beta$-D-galactosidase from sweet cherry, a nonclimacteric fruit. Journal of Agricultural and Food Chemistry 42: $2177-2182$.

Batisse C, Fils-Lycaon B and Buret M. (1994). Pectin changes in ripening cherry fruit. Journal of Food Science 59: 389-393.

Batisse C, Buret M and Coulomb PJ. (1996). Biochemical differences in cell wall of cherry fruit between soft and crisp fruit. Journal of Agricultural and Food Chemistry 44: 453457.

Bennett $\mathrm{AB}$ and Labavitch JM. (2008). Ethylene and ripening-regulated expression and function of fruit cell wall modifying proteins. Plant Science 175: 130-136.

Blumenkrantz N and Asboe-Hansen G. (1973). New method for quantitative determination of uronic acids. Analytical Biochemistry 54: 484-489. 
436 Bradford MM. (1976). A rapid and sensitive method for the quantitation of microgram 437 quantities of protein utilizing the principle of protein dye binding. Analytical $438 \quad$ Biochemistry 72: 248-254.

439 Cheng G, Duan X, Shi J, Lu W, Luo Y, Jiang W and Jiang Y. (2008). Effects of reactive 440 oxygen species on cellular wall disassembly of banana fruit during ripening. Food $441 \quad$ Chemistry 109: 319-324.

442 Choi C, Toivonen P, Wiersma PA and Kappel F. (2002a). Differences in levels of pectic 443 substances and firmness in fruit from six sweet cherry genotypes. Journal of the $444 \quad$ American Pomological Society 56: 197-201.

445 Choi C, Wiersma PA, Toivonen P and Kappel F. (2002b). Fruit growth, firmness and cell wall 446 hydrolytic enzyme activity during development of sweet cherry fruit treated with 447 gibberellic acid $\left(\mathrm{GA}_{3}\right)$. Journal of Horticultural Science and Biotechnology 77: 615-621. 448 Domínguez-Puigjaner E, Llop I, Vendrell M and Prat S. (1997). A cDNA clone highly 449 expressed in ripe banana fruit shows homology to pectate lyases. Plant Physiology 114: $450 \quad$ 1071-1076.

451 Duan X, Zhang H, Zhang D, Sheng J, Lin H and Jiang Y. (2011). Role of hydroxiyl radical in 452 modification of cell wall polysaccharides and aril breakdown during senescence of 453 harvested longan fruit. Food Chemistry 128: 203-207.

454 Dubois M, Gilles KA, Hamilton JK, Rebers PA and Smith F. (1956). Colorimetric method for 455 determination of sugars and related substances. Analytical Chemistry 28: 350-356.

456 Dumville JC and Fry SC. (2003). Solubilisation of tomato fruit pectins by ascorbate: a 457 possible non-enzymic mechanism of fruit softening. Planta 217: 951-961.

458 Fry SC. (1998). Oxidative scission of plant cell wall polysaccharides by ascorbate-induced 459 hydroxyl radicals. Biochemical Journal 332: 507-515. 
460 Gerardi C, Blando F, Santino A and Zacheo G. (2001). Purification and characterisation of a $461 \quad \beta$-glucosidase abundantly expressed in ripe sweet cherry (Prunus avium L.) fruit. Plant $462 \quad$ Science 160: 795-805.

463 Gerardi C, Blando F and Santino A. (2012). Purification and chemical characterisation of a 464 cell wall-associated $\beta$-galactosidase from mature sweet cherry (Prunus avium L.) fruit. 465 Plant Physiology and Biochemistry 61: 123-130.

466 Gillespie KM and Ainsworth EA. (2007). Measurement of reduced, oxidized and total $467 \quad$ ascorbate content in plants. Nature Protocols 2: 871-874.

468 Goulao LF and Oliveira CM. (2008). Cell wall modifications during fruit ripening: when a 469 fruit is not the fruit. Trends in Food Science and Technology 19: 4-25.

470 Goulao LF, Santos J, de Sousa I and Oliveira CM. (2007). Patterns of enzymatic activity of 471 cell wall-modifying enzymes during growth and ripening of apples. Postharvest Biology $472 \quad$ and Technology 43: 307-318.

473 Hagerman AE and Austin PJ. (1986). Continuous spectrophotometric assay for plant pectin 474 methyl-esterase. Journal of Agricultural and Food Chemistry 34: 440-444.

475 Jiménez-Bermúdez S, Redondo-Nevado J, Muñoz-Blanco J, Caballero JL, López-Aranda JM, 476 Valpuesta V, Pliego-Alfaro F, Quesada MA and Mercado JA. (2002). Manipulation of 477 strawberry fruit softening by antisense expression of a pectate lyase gene. Plant $478 \quad$ Physiology 128: 751-759.

479 Lara I, García P and Vendrell M. (2004). Modifications in cell wall composition after cold 480 storage of calcium-treated strawberry (Fragaria $\times$ ananassa Duch.) fruit. Postharvest $481 \quad$ Biology and Technology 34: 331-339.

482 Lara I, Belge B and Goulao LF. (2014). The fruit cuticle as a modulator of postharvest 483 quality. Postharvest Biology and Technology 87: 103-112. 
484 Lohani S, Trivedi PK and Nath P. (2004). Changes in activities of cell wall hydrolases during 485 ethylene-induced ripening in banana: effect of 1-MCP, ABA and IAA. Postharvest $486 \quad$ Biology and Technology 31: 119-126.

487 Miller GL. (1959). Use of dinitrosalicylic acid reagent for determination of reducing sugar. $488 \quad$ Analytical Chemistry 31: 426-428.

489 Moran F, Nasuno S and Starr MP. (1968). Extracellular and intracellular polygalacturonicacid 490 trans-eliminase of Erwinia carotovora. Archives of Biochemistry and Biophysics 123: $491 \quad 298-306$.

492 Ortiz A, Graell J and Lara I. (2011a). Preharvest calcium applications inhibit some cell wall493 modifying enzyme activities and delay cell wall disassembly at commercial harvest of 494 'Fuji Kiku-8' apples. Postharvest Biology and Technology 62: 161-167.

495 Ortiz A, Vendrell M and Lara I. (2011b). Softening and cell wall metabolism in late-season 496 peach in response to controlled atmosphere and 1-MCP treatment. Journal of 497 Horticultural Science and Biotechnology 86: 175-181.

498 Ortiz A, Graell J and Lara I. (2011c). Cell wall-modifying enzymes and firmness loss in 499 ripening 'Golden Reinders' apples: A comparison between calcium dips and ULO $500 \quad$ storage. Food Chemistry 128: 1072-1079.

501 Ortiz A, Seymour GB, Tucker GA and Lara I. (2010). Cell wall disassembly during the 502 melting phase of softening in 'Snow Queen' nectarines. Postharvest Biology and $503 \quad$ Technology 58: 88-92.

504 Parsons EP, Popopvsky S, Lohrey GT, Lu $\square$ S, Alkalai-Tuvia S, Perzelan Y, Paran I, Fallik E, 505 Jenks MA. (2012). Fruit cuticle lipid composition and fruit post-harvest water loss in an 506 advanced backcross generation of pepper (Capsicum sp.). Physiologia Plantarum 146: $507 \quad 15-25$. 
508 Pathak N and Sanwall GG. (1998). Multiple forms of polygalacturonase from banana fruits. $509 \quad$ Phytochemistry 48: 249-255.

510 Redgwell RJ, Melton LD and Brasch DJ. (1992). Cell wall dissolution in ripening kiwifruit 511 (Actinidia deliciosa). Plant Physiology 98: 71-81.

512 Romano GS, Cittadini ED, Pugh B and Schouten R. (2006). Sweet cherry quality in the 513 horticultural production chain. Stewart Postharvest Review 2: 6 (paper no. 9)

514 Salato GS, Ponce NMA, Raffo MD, Vicente AR and Stortz CA. (2013). Developmental 515 changes in cell wall polysaccharides from sweet cherry (Prunus avium L.) cultivars with $516 \quad$ contrasting firmness. Postharvest Biology and Technology 84: 66-73.

517 Selvendran RR and O'Neill MA. (1987). Isolation and analysis of cell walls from plant 518 material. In: Glick D (ed) Methods of Biochemical Analysis, vol. 32. New York: John $519 \quad$ Wiley Interscience, pp. 25-153.

520 Serrano M, Guillén F, Martínez-Romero D, Castillo S and Valero D. (2005). Chemical 521 constituents and antioxidant activity of sweet cherry at different ripening stages. Journal 522 of Agricultural and Food Chemistry 53: 2741-2745.

523 Vicente AR, Costa ML, Martínez GA, Chaves AR and Civello PM. (2005). Effect of heat 524 treatments on cell wall degradation and softening in strawberry fruit. Postharvest Biology 525 and Technology 38: 213-222.

526 Vogg G, Fischer S, Leide J, Emmanuel E, Jetter R, Levy AA, Riederer M. (2004). Tomato 527 fruit cuticular waxes and their effect on transpiration barrier properties: functional 528 characterization of a mutant deficient in a very-long-chain fatty acid $\beta$-ketoacyl-CoA $529 \quad$ synthase. Journal of Experimental Botany 55: 1404-1410.

530 Wei J, Fengwang M, Shi S, Qi X, Zhu Z and Yuan J. (2010). Changes and postharvest 531 regulation of activity and gene expression of enzymes related to cell wall degradation in 532 ripening apple fruit. Postharvest Biology and Technology 56: 147-154. 


\section{FUNDING ACKNOWLEDGEMENT}

B. B. is the recipient of a FI-DGR grant from AGAUR (Generalitat de Catalunya). This work was supported through the AGL2010-14801/ALI project, funded by the Ministerio de Ciencia e Innovación (MICINN) of Spain. Fruit samples were provided by J. M. Camats (Cireres de Corbins Camats-Carpi).

\section{DECLARATION OF CONFLICTING INTERESTS}

The Authors declare that there is no conflict of interest. 
1

2

3

4

5

6

7

8

9

10

11

12

13

14

15

16

17

18

19

20

21

22

23

24

25

26

27

28

29

30

31

32

33

34

35

36

37

38

39

40

41

42

43

44

45

46

47

48

49

50

51

52

53

54

55

56

57

58

59

60
Table 1. Maturity and quality indices of 'Celeste' and 'Somerset' sweet cherry fruit at commercial harvest.

\begin{tabular}{|c|c|c|}
\hline Parameter & 'Celeste' & 'Somerset' \\
\hline Weight (g) & $9.02 \pm 1.43$ & $10.49 \pm 1.49$ \\
\hline Diameter (mm) & $27.95 \pm 3.23$ & $30.73 \pm 2.08$ \\
\hline Firmness (Durofel units) & $77.7 \pm 8.25$ & $80.43 \pm 5.89$ \\
\hline Juiciness (mL 100g $\left.{ }^{-1} \mathrm{FW}\right)$ & $61.07 \pm 6.35$ & $65.37 \quad \pm 7.62$ \\
\hline SSC ( ${ }^{\circ}$ Brix $)$ & $16.07 \pm 0.57$ & $19.43 \pm 0.91$ \\
\hline TA $\left(\mathrm{g} \mathrm{L}^{-1}\right)$ & $6.70 \pm 0.35$ & $7.32 \pm 0.38$ \\
\hline Hue $\left(^{\circ}\right)$ & $21.88 \pm 2.82$ & $16.97 \pm 1.46$ \\
\hline Lightness $\left(L^{*}\right)$ & $33.51 \pm 0.17$ & $27.01 \quad \pm 0.32$ \\
\hline
\end{tabular}

Values represent means \pm SD of 30 or three (SSC, TA, juiciness) replicates. 
Table 2. Firmness (Durofel units), weight loss (\%) and decay incidence (\%) in 'Celeste' and 'Somerset' sweet cherries at harvest and after cold storage.

\begin{tabular}{lllll} 
Cultivar & Days $^{\boldsymbol{a}}$ & Firmness & Decay & Weight loss \\
\hline 'Celeste' & $\mathbf{0}$ & $77.7 \mathrm{a}$ & 0.0 & - \\
& $\mathbf{0 + 3}$ & $72.1 \mathrm{ab}$ & 0.0 & $9.6 \mathrm{c}$ \\
& $\mathbf{1 4 + 0}$ & $68.5 \mathrm{~b}$ & 0.0 & $15.8 \mathrm{~b}$ \\
& $\mathbf{1 4 + 3}$ & $69.9 \mathrm{~b}$ & 6.7 & $22.4 \mathrm{a}$ \\
\hline 'Somerset' & $\mathbf{0}$ & $80.4 \mathrm{~b}$ & 0.0 & - \\
& $\mathbf{0 + 3}$ & $77.2 \mathrm{~b}$ & 0.0 & $2.4 \mathrm{c}$ \\
& $\mathbf{1 4 + 0}$ & $86.5 \mathrm{a}$ & 8.5 & $7.2 \mathrm{~b}$ \\
& $\mathbf{1 4 + 3}$ & $82.1 \mathrm{ab}$ & 21.4 & $15.4 \mathrm{a}$ \\
\hline
\end{tabular}

Values are the means of 30 (firmness, weight loss) replicates. Decay incidence was evaluated as a percentage on the total number of fruit. For a given cultivar, means followed by different letters within the same column are significantly different at $P \leq 0.05$ (LSD test).

${ }^{a}$ Days at $0{ }^{\circ} \mathrm{C}+$ days at $20{ }^{\circ} \mathrm{C}$. 
1

2

3

4

5

6

7

8

9

10

11

12

13

14

15

16

17

18

19

20

21

22

23

24

25

26

27

28

29

30

31

32

33

34

35

36

37

38

39

40

41

42

43

44

45

46

47

48

49

50

51

52

53

54

55

56

57

58

59

60

Table 3. Yield of insoluble $(\mathrm{CWM})$ and $\mathrm{PAW}$-soluble $\left(\mathrm{PAW}_{\mathrm{sf}}\right)$ cell wall materials $(\% \mathrm{FW})$, and of fractions isolated from insoluble cell wall materials (\% CWM) in 'Celeste' and 'Somerset' sweet cherries at harvest and after cold storage.

\section{CWM fractions}

\begin{tabular}{llllllll} 
Cultivar & Days $^{\boldsymbol{a}}$ & $\mathbf{C W M}$ & $\mathbf{P A W}_{\text {sf }}$ & $\mathbf{W}_{\mathbf{s f}}$ & $\mathbf{C D T A}_{\mathbf{s f}}$ & $\mathbf{N a}_{\mathbf{2}} \mathbf{C O}_{\mathbf{3 s f}}$ & $\mathbf{K O H}_{\mathbf{s f}}$ \\
\hline${ }^{\prime}$ Celeste' & $\mathbf{0}$ & $1.086 \mathrm{c}$ & $0.049 \mathrm{ab}$ & $11.197 \mathrm{a}$ & $16.510 \mathrm{a}$ & $8.613 \mathrm{~b}$ & $0.938 \mathrm{c}$ \\
& $\mathbf{0 + 3}$ & $1.302 \mathrm{c}$ & $0.058 \mathrm{a}$ & $6.552 \mathrm{ab}$ & $17.710 \mathrm{a}$ & $13.674 \mathrm{a}$ & $2.406 \mathrm{a}$ \\
& $\mathbf{1 4 + 0}$ & $2.412 \mathrm{~b}$ & $0.020 \mathrm{c}$ & $2.438 \mathrm{~b}$ & $15.572 \mathrm{ab}$ & $7.860 \mathrm{~b}$ & $0.948 \mathrm{c}$ \\
& $\mathbf{1 4 + 3}$ & $3.751 \mathrm{a}$ & $0.029 \mathrm{bc}$ & $1.588 \mathrm{~b}$ & $11.964 \mathrm{~b}$ & $7.258 \mathrm{~b}$ & $1.833 \mathrm{~b}$ \\
\hline 'Somerset' & $\mathbf{0}$ & $1.186 \mathrm{~b}$ & $0.022 \mathrm{~b}$ & $3.495 \mathrm{a}$ & $18.204 \mathrm{ab}$ & $17.136 \mathrm{a}$ & $3.738 \mathrm{a}$ \\
& $\mathbf{0 + 3}$ & $2.205 \mathrm{a}$ & $0.019 \mathrm{~b}$ & $2.409 \mathrm{ab}$ & $17.232 \mathrm{~b}$ & $9.660 \mathrm{~b}$ & $1.267 \mathrm{~b}$ \\
& $\mathbf{1 4 + 0}$ & $2.153 \mathrm{a}$ & $0.028 \mathrm{a}$ & $1.078 \mathrm{~b}$ & $17.451 \mathrm{~b}$ & $10.098 \mathrm{~b}$ & $1.912 \mathrm{ab}$ \\
& $\mathbf{1 4 + 3}$ & $2.117 \mathrm{a}$ & $0.016 \mathrm{c}$ & $2.767 \mathrm{ab}$ & $20.098 \mathrm{a}$ & $14.750 \mathrm{ab}$ & $3.690 \mathrm{a}$ \\
\hline
\end{tabular}

Values are the means of three replicates. For a given cultivar, means followed by different letters within the same column are significantly different at $P \leq 0.05$ (LSD test).

${ }^{a}$ Days at $0{ }^{\circ} \mathrm{C}+$ days at $20^{\circ} \mathrm{C}$. 
Table 4. Content of ascorbic and dehydroascorbic acid $\left(\mu \mathrm{mol} \mathrm{gDW}^{-1}\right)$ in 'Celeste' and 'Somerset' sweet cherries at harvest and after cold storage.

\begin{tabular}{llll} 
Cultivar & Days $^{\boldsymbol{a}}$ & AA & DHA \\
\hline 'Celeste' & $\mathbf{0}$ & $9.041 \mathrm{a}$ & $5.532 \mathrm{~b}$ \\
& $\mathbf{0 + 3}$ & $11.766 \mathrm{a}$ & $6.629 \mathrm{a}$ \\
& $\mathbf{1 4 + \mathbf { 0 }}$ & $2.567 \mathrm{~b}$ & $0.240 \mathrm{~d}$ \\
& $\mathbf{1 4 + 3}$ & $8.134 \mathrm{a}$ & $1.082 \mathrm{c}$ \\
\hline 'Somerset' & $\mathbf{0}$ & $13.850 \mathrm{a}$ & $0.524 \mathrm{~b}$ \\
& $\mathbf{0 + 3}$ & $17.573 \mathrm{a}$ & $2.056 \mathrm{a}$ \\
& $\mathbf{1 4 + 0}$ & $6.884 \mathrm{~b}$ & $0.017 \mathrm{c}$ \\
& $\mathbf{1 4 + 3}$ & $13.966 \mathrm{a}$ & $0.253 \mathrm{~b}$ \\
\hline
\end{tabular}

Values are the means of three replicates. For a given cultivar, means followed by different letters within the same column are significantly different at $P \leq 0.05$ (LSD test).

${ }^{a}$ Days at $0{ }^{\circ} \mathrm{C}+$ days at $20^{\circ} \mathrm{C}$. 
1

2

3

4

5

6

7

8

9

10

11

12

13

14

15

16

17

18

19

20

21

22

23

24

25

26

27

28

29

30

31

32

33

34

35

36

37

38

39

40

41

42

43

44

45

46

47

48

49

50

51

52

53

54

55

56

57

58

59

60

Table 5. Specific activities $\left(\mathrm{U} \mathrm{mg}\right.$ protein $\left.^{-1}\right)$ of some pectolytic and non-pectolytic cell wall-modifying enzymes in 'Celeste' and 'Somerset' sweet cherries at harvest and after cold storage.

\begin{tabular}{llllll} 
Cultivar & Days $^{\boldsymbol{a}}$ & PL & AFase & $\boldsymbol{\beta}$-Xyl & EGase \\
\hline 'Celeste' & $\mathbf{0}$ & $1.026 \mathrm{~b}$ & $36.920 \mathrm{c}$ & $80.935 \mathrm{~b}$ & $11.943 \mathrm{ab}$ \\
& $\mathbf{0 + 3}$ & $1.294 \mathrm{~b}$ & $45.845 \mathrm{a}$ & $104.401 \mathrm{ab}$ & $18.708 \mathrm{a}$ \\
& $\mathbf{1 4 + 0}$ & $1.652 \mathrm{ab}$ & $40.926 \mathrm{~b}$ & $144.240 \mathrm{a}$ & $15.580 \mathrm{a}$ \\
& $\mathbf{1 4 + 3}$ & $2.137 \mathrm{a}$ & $43.517 \mathrm{ab}$ & $114.650 \mathrm{ab}$ & $6.712 \mathrm{~b}$ \\
\hline 'Somerset' & $\mathbf{0}$ & $2.712 \mathrm{~b}$ & $35.207 \mathrm{~b}$ & $129.844 \mathrm{~b}$ & $13.851 \mathrm{ab}$ \\
& $\mathbf{0 + 3}$ & $3.151 \mathrm{~b}$ & $38.402 \mathrm{~b}$ & $156.394 \mathrm{ab}$ & $11.574 \mathrm{~b}$ \\
& $\mathbf{1 4 + 0}$ & $2.287 \mathrm{~b}$ & $39.003 \mathrm{~b}$ & $60.025 \mathrm{c}$ & $15.545 \mathrm{a}$ \\
& $\mathbf{1 4 + 3}$ & $4.688 \mathrm{a}$ & $46.910 \mathrm{a}$ & $183.751 \mathrm{a}$ & $7.788 \mathrm{c}$
\end{tabular}

Values are the means of three replicates. For a given cultivar, means followed by different letters within the same column are significantly different at $P \leq 0.05$ (LSD test).

${ }^{a}$ Days at $0{ }^{\circ} \mathrm{C}+$ days at $20^{\circ} \mathrm{C}$. 


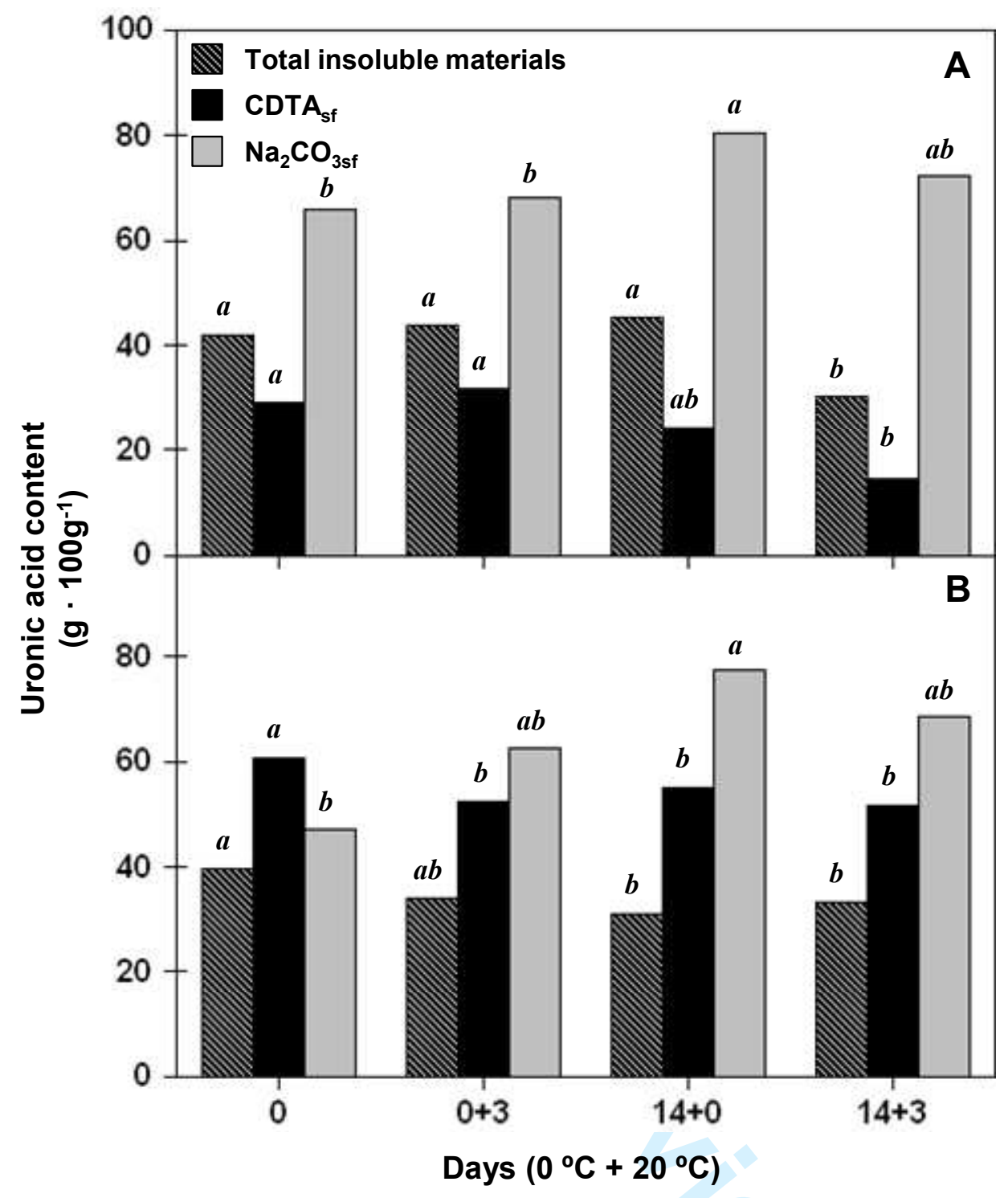

Figure 1. Uronic acid content $(\% \mathrm{w} / \mathrm{w})$ in total insoluble cell wall materials and in pectincontaining fractions isolated from 'Celeste' (A) and 'Somerset' (B) sweet cherries at harvest and after cold storage. Bars represent means of three replicates. For a given fraction, values bearing different letters are significantly different at $P \leq 0.05$ (LSD test). 


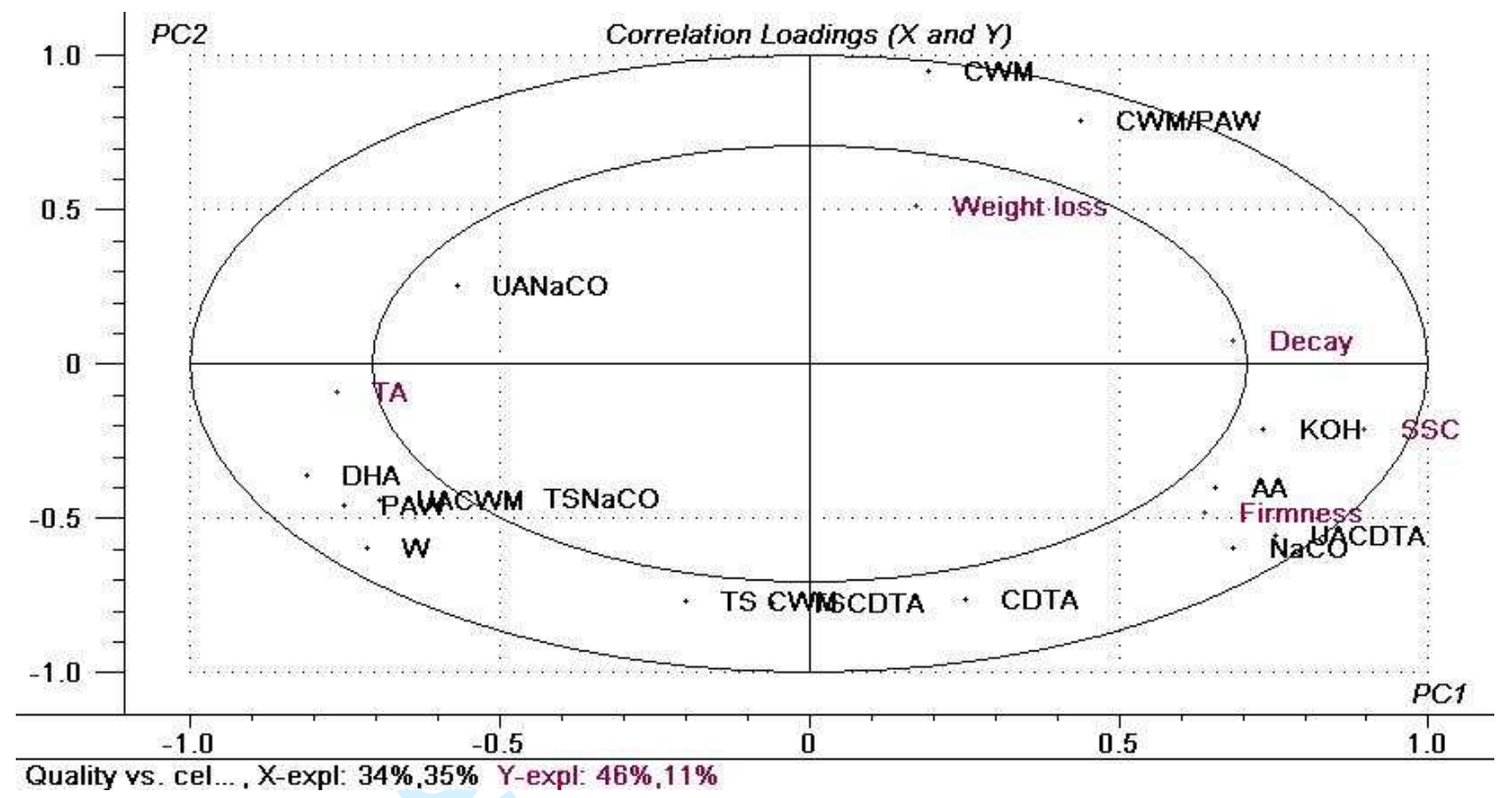

Figure 2. Correlation loadings plot of PC1 vs. PC2 corresponding to a PLSR model for quality attributes ( $Y$ variables) vs. yield and composition of cell wall fractions ( $X$ variables) isolated from 'Celeste' and 'Somerset' cherries after cold storage at 0 ${ }^{\circ} \mathrm{C}$ (AA, ascorbic acid; DHA, dehydroascorbic acid; UA and TS, uronic acid and total sugar content in a given cell wall fraction, respectively). 


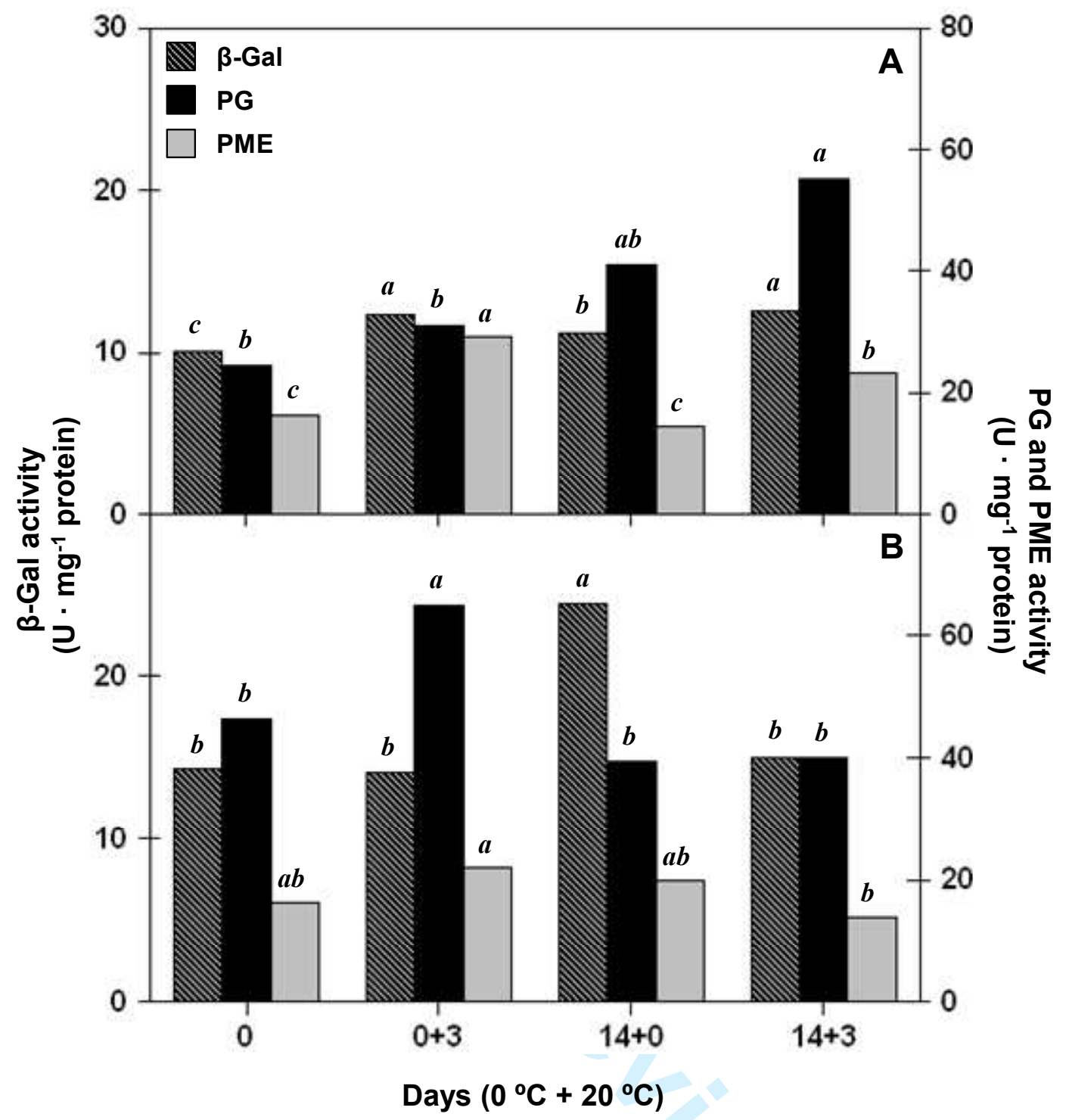

Figure 3. $\beta$-Galactosidase, polygalacturonase and pectinmethylesterase activities in 'Celeste' (A) and 'Somerset' (B) sweet cherries at harvest and after cold storage. Bars represent means of three replicates. For a given enzyme activity, values bearing different letters are significantly different at $P \leq 0.05$ (LSD test). 


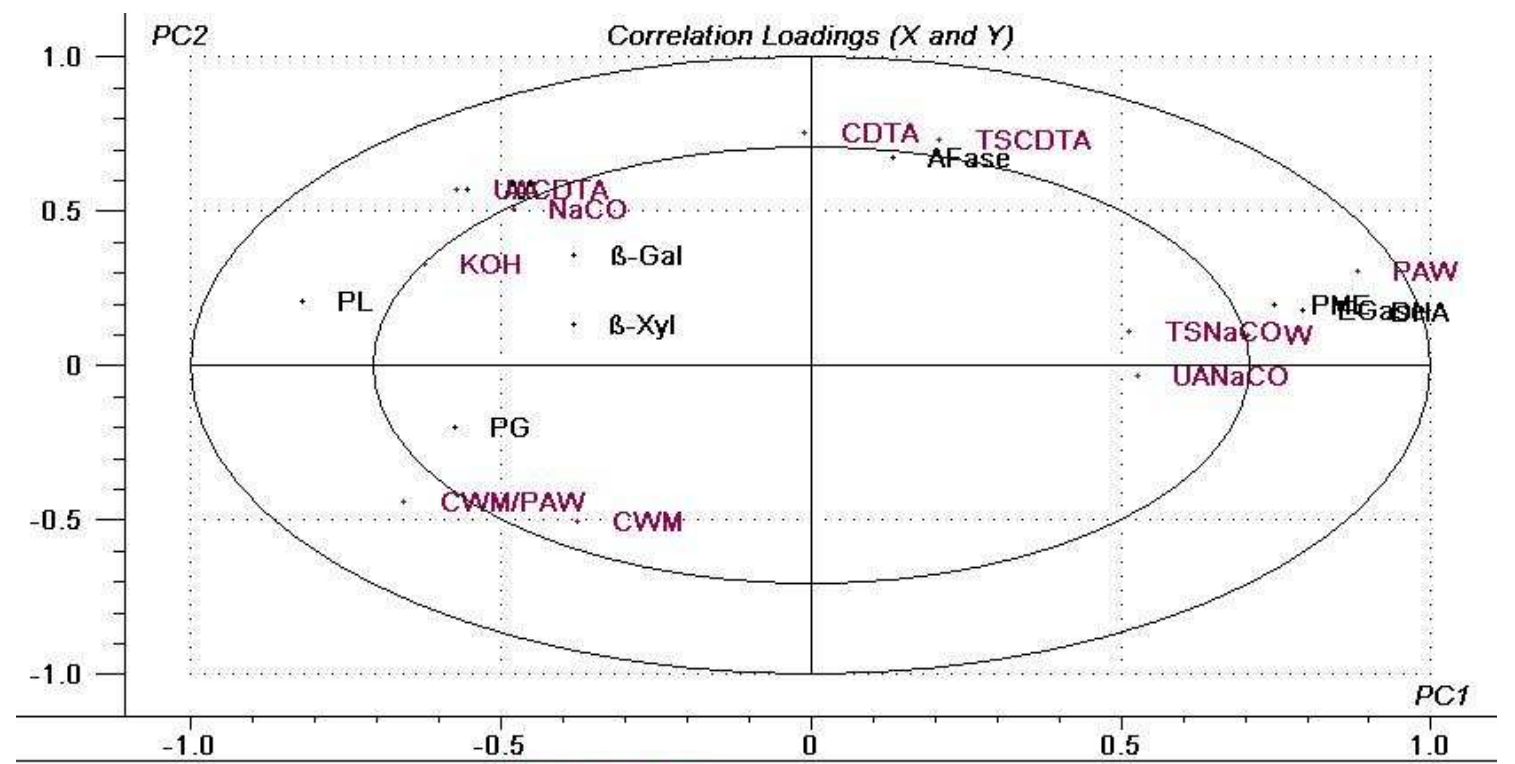

Cell wall vs. e... , X-expl: $40 \%, 12 \%$ Y-expl: $31 \%, 22 \%$

Figure 4. Correlation loadings plot of PC1 vs. PC2 corresponding to a PLSR model for yield and composition of cell wall fractions ( $Y$ variables) vs. cell wall-modifying enzyme activities and ascorbic acid content ( $X$ variables) in 'Celeste' and 'Somerset' cherries after cold storage at $0{ }^{\circ} \mathrm{C}$ (AA, ascorbic acid; DHA, dehydroascorbic acid; UA and TS, uronic acid and total sugar content in a given cell wall fraction, respectively). 